\title{
i am keeping my cultural hat on: exploring a 'culture-enabling' philosophy for/with children practice
}

\author{
peter paul elicor ${ }^{1}$ \\ ateneo de davao university, davao city, philippines \\ university of santo tomas, the graduate school \\ orcid id: https:/ / orcid.org/0000-0002-6427-0582
}

abstract

In this paper, I offer a preliminary sketch of a culture-enabling Philosophy for/with Children practice. It is an approach to engaging philosophically with children that aims to encourage the exercise of critical reflection at the level of their respective cultures. This kind of P4wC practice hopes to address the challenges in facilitating philosophical dialogues with culturally/ethnically-diverse groups, especially when prejudice and negative stereotypes towards cultural/ethnic minorities are prevalent. Its focus is on helping children become cognizant of their cultural situatedness and its impact on their thinking and attitude towards dialogue. Underlying this practice is the assumption that Philosophy is fundamentally a worldview and a method that is embedded in the culture where it is created, validated, and used. Such a manner of doing philosophy recognizes that children are active bearers of culture and are entitled to educational opportunities, like $\mathrm{P} 4 \mathrm{wC}$, that can empower them to think for themselves and with others while staying grounded in their cultural backgrounds. Thus, the community of inquiry functions as a caring space where intercultural understanding and critical affirmation of cultures are fostered and sustained. In connection, I suggest that a culture-enabling P4wC teacher should have three desired traits: a) openness to various cultural resources and frames, b) a sense of critical positionality, and c) partiality to the culturally marginalized.

keywords: philosophy for/with children; culture; marginalization; culture-enabling practice.

\section{me dejaré el sombrero cultural puesto: exploración de una práctica "culturalmente habilitadora" de la filosofía para/con niños}

resumen

En este artículo, ofrezco un boceto preliminar de una práctica de la Filosofía para/con Niños culturalmente habilitadora. Es un enfoque sobre las relaciones filosóficas con niños que apunta a alentar el ejercicio de la reflexión crítica a nivel de sus respectivas culturas. Este tipo de práctica de $\mathrm{Fp} / \mathrm{cN}$ espera abordar los desafíos que forman parte de facilitar diálogos filosóficos en grupos cultural o étnicamente diversos, especialmente cuando prevalecen los prejuicios y los estereotipos negativos sobre las minorías culturales o étnicas. Su foco central es ayudar a los niños a tomar conciencia de su estar situados culturalmente y del correspondiente impacto que ello tiene sobre su pensamiento y su actitud hacia el diálogo. Subyace a esta práctica el supuesto de que la Filosofía es fundamentalmente una cosmovisión y un método emplazado en la cultura en la cual es creado, validado y usado. Esta manera de hacer filosofía reconoce que los niños son portadores activos de cultura y tienen derecho a oportunidades educativas, como

${ }^{1}$ E-mail: peterelicor@gmail.com 
i am keeping my cultural hat on: exploring a 'culture-enabling' philosophy for/with children practice

$\mathrm{Fp} / \mathrm{cN}$, que les habiliten la posibilidad de pensar por sí mismos y con otros al mismo tiempo que se mantienen enraizados en su trasfondo cultural. Por lo tanto, la Comunidad de Indagación funciona como un espacio de cuidado donde el entendimiento intercultural y la afirmación crítica de las culturas son fomentados y sostenidos. En relación a esto, sugiero que un profesor de $\mathrm{Fp} / \mathrm{cN}$ culturalmente habilitador debería tener tres rasgos deseados: a) apertura a variados recursos y marcos culturales, b) un sentido de posicionamiento crítico, y c) parcialidad a favor de los marginados culturalmente.

palabras clave: filosofía para/con niños; cultura; marginalización; práctica culturalmente habilitadora.

\section{mantenho meu chapéu cultural: explorando uma filosofia "habilitadora da cultura" para / com a prática infantil}

\section{resumo}

Neste artigo, apresento um esboço preliminar de uma prática de Filosofia para/com crianças que culturalmente habilitadora. É um enfoque sobre as relações filosóficas com crianças que visa encorajar o exercício da reflexão crítica no nível de suas respectivas culturas. Este tipo de prática de $\mathrm{FpcC}$ espera abordar os que formam parte de facilitar diálogos filosóficos em grupos culturalmente ou etnicamente diversos, especialmente quando prevalecem os prejuízos e os estereótipos negativos em relação às minorias culturais ou étnicas. Seu foco central é ajudar as crianças a tomar consciência de sua situação cultural e o correspondente impacto que isso tem em seu pensamento e atitude em relação ao diálogo. Subjacente a esta prática está o pressuposto de que a Filosofia é fundamentalmente uma visão de mundo e um método que está incorporado na cultura onde é criada, validada e usada. Tal maneira de fazer filosofia reconhece que as crianças são portadoras ativas de cultura e têm direito a oportunidades educativas, como o FpcC, que pode capacitá-las a pensar por si mesmas e com os outros enquanto permanecem enraizadas em suas origens culturais. Assim, a Comunidade de Investigação funciona como um espaço de cuidado onde a compreensão intercultural e a afirmação crítica das culturas são fomentadas e sustentadas. Em relação a isso, sugiro que um professor FpcC capacitador de cultura deve ter três características desejadas: a) abertura a vários recursos e perspectivas culturais, b) um senso de posição crítica e c) parcialidade para os marginalizados culturalmente.

palavras-chave: filosofia para/com crianças; cultura; marginalização; prática capacitadora de cultura. 


\section{introduction}

This paper begins with the assumption that Philosophy for/with Children $(\mathrm{P} 4 \mathrm{wC})$, as a program, entails empowering children to exercise philosophical reflection on their respective cultural upbringing in a manner that is critical and caring. Patterned from the reflective model of education, $\mathrm{P} 4 \mathrm{wC}$ bears the potential for creating critical and caring spaces that allow the constructive examination of cultural beliefs and practices (Echeverria, 2009; Preece \& Juperi, 2014, Makaiau, 2017). The Community of Inquiry functions as an open space where intercultural understanding and critical affirmation of cultures are fostered and sustained. Individually, this process nurtures the capacity to take a subjective distance from one's cultural upbringing, while collectively, encourages tolerance for and deeper understanding of cultural differences.

This paper has four main parts. The first part draws from $\mathrm{P} 4 \mathrm{wC}$ literature and describes how the Community of Inquiry can help facilitate intercultural understanding and dialogue. The second part consists of a general definition of cultureenabling practice and a discussion on culture as a resource and a frame. This is followed by an analysis on how culture complements philosophy understood as a worldview and a method. The third part lays down three goals of a culture-enabling practice. Finally, the fourth part is a discussion on some desired traits of a culture-enabling $\mathrm{P} 4 \mathrm{wC}$ teacher.

\section{1. intercultural dialogue in the community of inquiry}

The necessity for intercultural understanding and dialogue is a much needed response to our rapidly changing and increasingly diversified globalized world. Drawing from Fornet-Betancourt, Oliverio points out that the COI provides a dialogical space whereby an inter- or intra-cultural dialogue is cultivated among learners and educators owing to its inherent inter-subjective process (2017). As a philosophical practice, $\mathrm{P} 4 \mathrm{wC}$ is one of the educational ways to mobilize philosophy

...to trigger "the critical reflection in the members of each single culture" ${ }^{\prime \prime}$ and, accordingly, to equip subjects with the cognitive and affective tools and resources to work "intersubjectively at the level of 
i am keeping my cultural hat on: exploring a 'culture-enabling' philosophy for/with children practice

one's own way of thinking and intraculturally at the level of one's own culture $^{\prime \prime} \ldots$ and to cultivate, therefore, an interculturally qualified intersubjectivity, in which borders are experienced both as form-giving factors and as places of encounter that enable people to discover the constitutive relation of subjectivity to the otherness (Oliverio, 2017, p.5).

Culture should be construed not as a delineating category separating one position from another, but as "places of encounter" where cultural perspectives interact and are positively transformed. A genuine intercultural dialogue proceeds only from a genuine inter-subjective encounter with a culturally-positioned other. Such inter-subjective encounter "enhances intercultural competences, reinforces individual and social sensitivity to otherness and diversity, and gives strength to any attempt to support differences" (Tibaldeo, 2017, p.124). The COI, with its priority for philosophical inquiry and emphasis on care through mutual respect, overcomes the 'us vs. them' binary, thereby transforming "cultural borders into bridges" (FornetBetancourt, 1998; cited in Oliverio, 2017).

However, the aim to nurture independent thinking among children by providing them opportunities to inquire and dialogue freely might clash with some cultures that do not encourage questioning among children. In some cultures, respect for the elders is commonly displayed with an unquestioning obedience, which is often expected among the young. Does this seeming tension between the cultural background of children, on the one hand, and the philosophical culture fostered by the $\mathrm{COI}$, on the other, cancel out the significance of $\mathrm{P} 4 \mathrm{wC}$ ? In this regard, Echeverria highlights the importance of considering the compatibility of the aims of $\mathrm{P} 4 \mathrm{wC}$ with the "desires and expectations of [the] community", especially when engaging with children who do not belong to the dominant culture (Echeverria, 2009, p.664). Despite certain epistemological and practical incompatibilities stemming from the differences in culture, the COI can provide a space for intercultural understanding where the goal is "to know the other, to enrich oneself from what the other has to offer and to be in a position to enrich the other through the interaction with one's own culture" (ibid., 
p.666). Needless to say, to nurture intercultural understanding and dialogue, it is crucial that $\mathrm{P} 4 \mathrm{wC}$ has to be culturally relevant and responsive.

The Philosophy for Children Hawaii (p4cHI) focuses precisely on establishing intellectually safe communities of inquiry where "the participants' cultures, languages, histories, socio-economic backgrounds, and other aspects of their identities are included and validated during the building of relationships and the co-construction of knowledge" (Makaiau, 2017, p.99). Jackson observed that the curriculum Lipman created is "too limiting with its focus on Western philosophical traditions and culture" (2012, p.5). Drawing from the scholarship on culturally-responsive teaching, Makaiau avers that respect and recognition of the various cultural differences students and teachers bring in the classroom are integral in creating a learning experience that follows the principles of social justice.

Other than providing an intellectually safe environment that takes cognizance of the cultural sensibilities of the locale, the COI also creates a critical space for some cultural beliefs and practices to be caringly examined. Not all cultures are reasonably acceptable, as some are deeply unjust, especially towards those who belong to the minority. Intercultural understanding therefore entails avoiding what Turgeon describes as "simplistic dismissal of differences or the uncritical embracing of them" (2005, p.104). Far from romanticizing culture, philosophical thinking in the COI should draw attention to the patterns of thinking and the assumptions embedded in one's culture that could block intercultural understanding and appreciation of differences. For this reason, Santi argues that what one accepts as "common sense acquired in a culture has to be explored and discovered anew each time, as we need to explicate the implicit assumptions, dogma, and prejudices which lie behind beliefs" (2014, p.293).

\section{2. what is a culture-enabling p4wc practice?}

A culture-enabling $\mathrm{P} 4 \mathrm{wC}$ practice is an approach to engaging philosophically with children that aims to enable them to exercise critical reflection at the level of their respective cultures. This is aligned with Thomas Jackson's "little-p philosophy," which 
i am keeping my cultural hat on: exploring a 'culture-enabling' philosophy for/with children practice

posits that philosophy is constituted by the "set of beliefs that we all possess to make sense of the world" $(2012$, p.5). It follows that our philosophical worldviews result from our "situatedness in the world and our responses to them" (ibid.).

Accordingly, building a COI in a culture-enabling manner entails empowering children to exercise philosophical thinking based on their unique cultural positions. Such a process does not silence the cultural orientations, perspectives, and thinking styles of children; instead, it acknowledges the plurality of cultural resources overlapping in the COI, thereby avoiding the privileging of a particular cultural standpoint. Underlying this practice is the assumption that culture is a fertile ground for philosophical thinking that supplies the content, context, meaning, and method. A child's unique culture and language, among other categorizations for social differentiation, serve as essential filters through which she acquires an understanding of the world. Thus, philosophical reflection should be carried out without turning a blind eye to the unique and particular meanings stemming from one's cultural background.

A culture-enabling practice has four general intentions: a) to make children recognize their inherent ability to think philosophically, b) to make children realize the importance of their cultural upbringing as integral in shaping their epistemic position, c) to encourage children to bring into the dialogue their unique cultural experiences, fostering intercultural understanding, and d) to equip children with the skill to exercise critical appreciation of their own culture, thereby enabling them to determine the factors (e.g., assumptions, beliefs, practices, traditions) that either support or block a philosophical dialogue. In each of these intentions, each child's culture is recognized as a legitimate reference that can be articulated, inquired, and expressed philosophically, thus making it available for dialogue. Simply put, this practice emphasizes the entanglement of philosophical thinking with and through culture. 
2.1 culture as a resource and a frame

A common approach to cultural studies is to view cultures as having essences (Bruya, 2017). These essences serve as distinct markers that help people understand the general features and characteristics (e.g., beliefs, practices, and traditions) of those who belong to a particular cultural group. Such an approach assumes that culture is a set of acquired patterns of thought and behavior that characterize a group of people. Here, culture is understood as a resource that provides the fundamental assumptions and value orientations that guide peoples' beliefs and actions. Embedded in it are the repeated mental processes germane in a particular group. In this sense, culture serves as an 'identity marker' that determines one's (or a group's) uniqueness.

Another interpretation of culture maintains the notion that it is a dynamic frame that guides cognitive and behavioral responses. This interpretation follows the constructivist approach in which culture is "internalized in the form of a loose network of domain-specific knowledge structures, such as categories and implicit theories" (Hong et al., 2000, p.710). In this view, human beings are not understood as mere passive bearers of cultural resources. Instead, they actively "express and exercise agency via culture, and apply cultural knowledge flexibly and discriminatively across situations" (Bruya, 2017, p.1000). This is evident among those who have internalized at least two cultures. Through exposure, assimilation, and socialization, they can 'switch frames' from one cultural viewpoint to another according to the situation or stimulus encountered (Hong et al., 2000, p.710). What is implied here is that one can 'mentally hold' several cultural frames even if these are conflicting and contradictory. Thus, one is not necessarily stuck within her cultural context as she can nurture a bi- or multicultural mind.

\section{2 complementing culture and philosophy}

A culture-enabling practice utilizes the definition of culture mentioned above (resource and frame), which complement the two interpretations of Philosophy deployed in this paper, namely, as a worldview and as a method. 
i am keeping my cultural hat on: exploring a 'culture-enabling' philosophy for/with children practice

\section{3 culture as a resource vis-a-vis philosophy as a worldview}

In a culture-enabling practice, exercising philosophical thinking entails critical reflection on culture treated as a resource. Here, philosophy (or better yet, philosophies ${ }^{2}$ ) are primarily understood as the general orientation of the world and man's place in it, which inform and shape the socio-political, religious, and moral ideals of a particular group of people. As a worldview, philosophy is deeply embedded in a specific culture. It manifests in peoples' practices, beliefs, and traditions all of which are presupposed by a distinct understanding of reality. In this regard, philosophy underlies the set of ideas, values, and norms that make up a particular worldview. It contains the ontological presuppositions that provide the basis, meaning and justification of one's understanding of the world. For example, morality, ethics, politics and aesthetics are informed and influenced by culture, shaping the behaviors, relationships, and practices of those who identify with it. With this interpretation, Philosophy signifies the 'viewed.'

Moreover, exercising philosophical thinking based on culture as a resource treats philosophy as content. Generally, in engaging philosophically with children, one basic question that a practitioner should ask is: what will they philosophize about? A philosophical dialogue always begins from where the children are, i.e., their unique experiences, questions, feelings and thoughts. A culture-enabling practice proceeds further by inquiring into the connection of these experiences, questions, feelings and thoughts with their cultural background. In other words, a philosophical dialogue takes off from the children's narratives, and then leads them towards the intangible cultural resources underpinning their experiences. For instance, if an indigenous child shares her thoughts and experiences about her home, this may be deepened by inquiring into how her community views their ancestral domain and, in general, nature. Philosophy as a worldview treats cultural resources as contents for

\footnotetext{
${ }^{2}$ Here, I am following philosophical pluralism and some themes in postcolonial studies, which challenge the 'master key' approach, or the philosophical method that insists on an overarching theory that can 'unlock' various forms of philosophical thinking. In rejecting this view, it makes more sense to use 'philosophies' than the singular 'Philosophy'.
} 
philosophical thinking and reflection, which can be rationally articulated, examined, and juxtaposed with other views. In this sense, culture is a form of ontology.

\section{4 culture as a frame vis-a-vis philosophy as a method}

Following the dynamic view of culture, exercising philosophical thinking entails critical reflection on culture treated as a frame. Here, Philosophy is understood as a method or the process involved in arriving at a particular view of the world. While the first sense of culture treats philosophy as that which is viewed, this second sense of culture treats philosophy as the viewing. This notion corresponds to the interpretation of culture as domain-specific structures, such as cultural constructs, criteria and categories. Philosophy as a method (or viewing reality) is not limited to the dominant standards and processes followed in most (western) philosophical discourses. Therefore, a culture-enabling practice is sensitive to other equally important criteria other than the usual 'yardsticks' for philosophical thinking, such as objectivity, impartiality, comprehensiveness, and consistency.

A culture-enabling practice considers the following questions: What are the alternative ways of exercising philosophical thinking? What are the other criteria for acquiring, generating, and validating philosophical knowledge in the COI? These questions highlight the fact that a particular philosophy (again, for instance, how indigenous communities view their ancestral domain) is not a mere repository of 'nuggets of wisdom' that can be captured, copied or transferred. Rather, such a view primarily consists of inter-generational patterns of thinking, doing and being that elude objectification and categorization. In this regard, the indigenous belief that their land is not a property to be owned but a sacred space shared with and protected for the present and future generations is a philosophical frame. Epistemologically speaking, it is a distinct way of understanding ownership and accountability to Mother Earth, which is obviously different from non-indigenous perspectives towards nature. This way of viewing humans' relationship to land foregrounds an intuitive and embodied concept of inherent interconnectivity within the whole of creation, between 
i am keeping my cultural hat on: exploring a 'culture-enabling' philosophy for/with children practice

and among the living and non-living, whether in the past, present or future. It is kind of thinking that demands the genuine effort of seeing reality in a continuum where all beings are interrelated, instead of viewing the world in a fragmented, disengaged and reductive way. In this sense, culture as a frame is treated as an epistemology. It sets the criteria for determining how and why certain forms of knowledge are known, used and validated.

\section{3. goals of a culture-enabling $p 4 w c$ practice}

\section{1 to think from one's cultural standpoint}

A culture-enabling practice emphasizes how culture is entangled with philosophy and educational practice. This view, nevertheless, is not widely recognized by philosophers and educators. For example, Geneva Gay observes that education, particularly mainstream neoliberal education, is guilty of what she calls "cultural blindness," which proceeds from the belief that "education has nothing to do with cultures and heritages," and that "good teaching is transcendent...[and] identical for all students under all circumstances" (2000, p.21). Cultural blindness flattens the various positionalities of learners and alienates them from their cultural identities. Philosophy, let alone teaching it to children, does not occur in a vacuum. It behooves $\mathrm{P} 4 \mathrm{wC}$ practitioners and researchers alike to avoid a culturally-blind approach in engaging with children.

While objectivity and impartiality are desirable criteria in philosophical dialogues, one cannot unambiguously impose these on children, especially the less privileged and vulnerable. Due to their exposure to negative stereotypes, most of them have a fragile sense of identity, affecting their perception of their epistemic and cultural position in the COI. These stereotypes profoundly affect their views, confidence, and the way they relate with other children. For this reason, when a practitioner ignores the cultural continuity in a child's thinking, the latter would feel cut off from the others. Consequently, it disables her capacity to participate as a co-inquirer in the dialogue freely and actively. 


\section{2 to critically appreciate culture and its impact on thinking}

A culture-enabling practice stresses the impact of one's cultural situatedness in the process of thinking. However, this practice does not idealize, much less romanticize, culture(s). Instead, it challenges practitioners to be conscious of culture's rootedness on the geographical and historical contingencies from which it has emerged and developed. It cannot be emphasized enough that some cultures maintain deeplyingrained beliefs and practices that are antagonistic to the process of philosophical inquiry. Thus, a culture-enabling practice entails addressing ethnocentrism and cultural dogmatism as these inevitably block philosophical thinking and dialogue.

A culture-enabling practice challenges children and teachers to reconsider their cultural sensibilities and examine the dominant criteria underlying their views. The importance placed on culture does not imply that it should be treated as fixed and pure, thereby incontestable reality. For instance, it is a fact that there are thinking patterns and practices prevalent in indigenous cultures that could disable the necessary conditions for dialogue (e.g., tribalism). Rather than building bridges, these cultural elements create barriers instead. Thus, a culture-enabling practice fosters critical appreciation to help children discern critically (but caringly) the strengths and limitations of worldviews. This process is a self-reflexive approach that requires a constant reflection on the various aspects of one's cultural identity, thereby determining which elements are important and which ones need rethinking, critiquing and even transformation. In such a process, culture as a resource lends itself open to be critically appraised through the lens of other cultural frames.

\section{3 to nurture multicultural thinking}

A culture-enabling practice maintains the notion that the deployment of multicultural contents and methods in philosophical dialogues with any children is not only desirable but crucially important in multicultural societies. The assumption here is that understanding a cultural frame other than one's own is necessary to develop 
i am keeping my cultural hat on: exploring a 'culture-enabling' philosophy for/with children practice

multicultural thinking. Such thinking consists of the openness to view one's experiences through various cultural lenses. It entails letting one's unique perspective of the world be perceived and examined through a different cultural standpoint, as one does to another. This ability habituates children to recognize the importance of building respectful inter-subjective interactions with other children from various cultures, a sine qua non for intercultural understanding, especially if exercised in a COI over a longer period.

Enabling children to exercise philosophical thinking based on their respective cultures does not risk favoring a particular cultural standpoint. Rather, it foregrounds the necessity of preserving the diversity of cultural identities and perspectives. These are crucial in gaining a broader understanding of a pluralistic society and what it means to be part of it. Nurturing multicultural thinking involves learning multiple cultural resources and frames to enrich one's own (and the others') cultural horizons. Accordingly, this entails recognizing and integrating other (and less recognized) forms of knowledge systems and epistemologies.

\section{4 desired traits of a culture-enabling p4wc teacher}

In this final section, I discuss three essential characteristics that a cultureenabling P4wC teacher should possess, namely: a) openness to various cultural resources and frames, b) critical positionality, and c) partiality to the culturallymarginalized. It is vital to cultivate these qualities to enable children to exercise their ability to exercise philosophical thinking based on their cultural standpoints.

\section{1 openness to various cultural resources and frames}

A culture-enabling teacher must have the openness towards other cultural resources and frames. Concretely, this means that she has a working knowledge of the cultures of children who are involved in the COI. Her level of understanding about the various cultures represented in the classroom must be sufficient enough to be able to supply what children do not, or naively, know. She may begin by making an effort to 
understand and appreciate the history, cultural artifacts, key figures, and local stories that make a particular culture (or ethnolinguistic community) distinct from others. This can be done by consulting the elders of the community, indigenous teachers, parents and scholars. Also, there are existing ethnographic works by anthropologists that can provide important information about their ways of life and worldview. However, due diligence is required when reading the "legacies of our ethnographic ancestors," as some of them may contain flawed ascriptions of meaning that can obscure crucial aspects of their beliefs and practices (Gatmaytan, 2004).

Most importantly, she must have an adequate knowledge and genuine appreciation of her own culture. A person who sees the value of her cultural roots has less difficulty seeing the value of others' cultures. In a sense, this quality challenges the idea that a $\mathrm{P} 4 \mathrm{wC}$ teacher is a mere facilitator of philosophical dialogues. While the skills in facilitation and knowledge of the procedures and principles of the COI are fundamental, her grasp of culture is equally important as it equips her with the knowledge of cultural resources (viewed) as well as of the method (viewing) of thinking that is active in a COI.

Moreover, knowledge or proficiency in children's local language is desirable. A teacher has to be conscious of the implications of using a dominant language, as it could have a 'double-edged' effect. On the one hand, it enables one to communicate, but, on the other, it could reproduce power structures and subtly maintain the subtle forms of domination and marginalization. According to Giroux and McLaren, language is "not a transparent window to the world but rather as a symbolic medium that actively shapes and transforms the world" (1992, p.12). Language, in this sense, functions to mediate reality and not merely serve as its reflection. Meanings are created through language as it contributes to the social construction of reality. Thus, imposing a language to be utilized in philosophical dialogue affects how a child ascribes meaning to her own experiences, thereby affecting her perception of reality. Acknowledging that the use of spoken language is integral in the COI, it is crucial to ask how to employ 
i am keeping my cultural hat on: exploring a 'culture-enabling' philosophy for/with children practice

language without making it an "instigator and purveyor of colonial power" (Gandhi, 1998, p.142).

\section{2 critical positionality}

Another trait that is important for a culture-enabling teacher is what I refer to as critical positionality. Positionality refers to the social conditions that cause, maintain, and change our social position, thereby shaping how we are differently situated in social hierarchies of power and privilege (Alcoff, 1988; Qin, 2016). These conditions consist of, but are not limited to, the varying economic, geopolitical, socio-cultural and linguistic categories that shape our subjectivity and identity. As a concept, positionality describes our shifting social position within the 'web' of relations we engage with. In the context of a classroom, an educator's awareness of her own and her students' positionality is crucial not least because "the fashioning of one's voice in the classroom is largely constituted by one's position there" (Maher \& Tetreault, 1993, p.118). Insofar as $\mathrm{P} 4 \mathrm{wC}$ aims to develop children's ability to find and express their respective voices within the COI, cognizance to positionality cannot be understated.

On the other hand, critical positionality refers to the awareness of the impact of one's positionality on another knower's position. This is predicated on the assumption that inter-subjective relations demand the recognition of epistemic equality between knowing subjects. Concretely, it means exercising conscious sensitivity towards the ethical consequences of being entangled with other people's positionalities. Such conscious sensitivity presupposes openness, responsiveness and empathy towards the less privileged others inferiorly positioned in the classroom and, in general, the community. In this regard, as an attitude (or better yet, a virtue), it denotes an intellectual posture that seeks to elevate the other, not degrade; or a mental disposition that aims to dignify, not humiliate. One has a sense of critical positionality if she deliberately enables the less privileged and the vulnerable to assert themselves as coequals or co-inquirers in the dialogue. An important implication of fostering critical positionality in $\mathrm{P} 4 \mathrm{wC}$ is the imperative to make everyone in the COI recognize the 
multiple ways of thinking without allowing any form of identity prejudice to derail the dialogical process (Elicor, 2020). This means enabling a child to speak and be heard without fear of being criticized based on her ethnicity, language, gender or social status. For these reasons, critical positionality is a critical conceptual complement in building a COI.

\section{3 partiality to the culturally marginalized}

The priority of dialogue among equal knowers in a COI democratizes both students' and teachers' capacity for thinking, speaking and listening, and likewise, being spoken to and being listened to. $\mathrm{P} 4 \mathrm{wC}$ 's emphasis on dialogue positions all members on an equal footing to pursue questions, share insights, probe assumptions, and correct unsound arguments. In such dialogical process, the COI reverses the teacher's priority: from transmitting knowledge to facilitating a democratic inquiry. Among the essential criteria for such a democratic dialogue are objectivity and impartiality. These are crucial in keeping the integrity of the procedures of dialogical inquiry and are supposed to uphold equality among children regardless of their sociocultural differences.

While this treatment of the teacher's role sounds progressive, it however runs the risk of endorsing a notion of an impartial teacher (Kohan, 1995). Such a teacher is likened to a 'referee' whose role is to maintain and enforce the purportedly objective rules of a game, while maintaining detachment and neutrality. It cannot be emphasized enough that the criteria of objectivity and impartiality ${ }^{3}$ become problematic when one considers the broader socio-cultural context. In societies steeped in various forms of injustice (political, cultural, epistemic, etc), it is not difficult to grasp the fact that a lot of children are socio-culturally situated in vulnerable positions. In these contexts, impartiality becomes complicity to the dominant culture and its unjust social order.

\footnotetext{
${ }^{3}$ The assumption here is that objectivity is always dependent on normative criteria, which are tied up with the dominant narratives or discourses of a particular society. For instance, there was a time in human history that the Jews were "objectively" considered an inferior race. This is also true for the blacks and women who were also "objectively" believed to be inferior human beings at one point in history.
} 
i am keeping my cultural hat on: exploring a 'culture-enabling' philosophy for/with children practice

For instance, in certain groups where epistemic injustice is prevalent, a teacher should not allow dominant views undervalue the pressing issues that disable marginalized children from engaging actively and freely in the dialogue.

This does not mean that a teacher abandons impartiality and objectivity altogether since, as already mentioned, these are valuable in the facilitation of dialogues. However, considering the reality of inequality in the classroom, a teacher must exercise some degree of partiality towards the most vulnerable and socioculturally disadvantaged. ${ }^{4}$ In other words, her partiality is expressed through informed empathy towards the less privileged. This means adopting a conscious preference for the culturally marginalized present in the COI. These children remain disabled from exercising their ability to think philosophically as long as they are subjected to prejudice. Placed in their situation, one will begin to understand why some of them see their culture as an obstacle to be overcome, not an asset to be shared.

\section{concluding remarks}

This paper offers some preliminary sketches of a culture-enabling practice. It follows the fundamental commitments of $\mathrm{P} 4 \mathrm{wC}$ and builds upon its methodology in appropriating philosophical inquiry among culturally/ethnically marginalized children. Specifically, this kind of approach to $\mathrm{P} 4 \mathrm{wC}$ is predicated on the premise that philosophy fundamentally arises from the culture where it is created, validated, and used. A child's ability to think philosophically is enabled when the worldviews presupposed in her culture are given serious attention in the dialogues. With this assumption, a culture-enabling practice entails making children become attentive to their cultural situated-ness and its impact on their thinking and attitude towards dialogue. It fosters not only a critical appreciation of their cultural standpoint, but also promotes the value of intercultural understanding. Moreover, a culture-enabling

\footnotetext{
${ }^{4}$ In parallel, Kohan underlines one of the sharp differences between Friere's and Lipman's notions concerning education, that is, neutrality. Unlike Lipman who maintains impartiality in the COI, Friere, Kohan notes, "has been emphatically challenging neutrality and arguing that the teacher should take sides with the oppressed" (See Kohan, 2018).
} 
practice helps unmask the various forms and locations where negative stereotypes towards cultural identities occur. Children are wronged when they are disrespected and devalued as potential co-inquirers in a COI. Therefore, enabling children to engage in a dialogical inquiry that is sensitive to their respective cultures addresses the problem of cultural-epistemic oppression experienced by many culturally marginalized children.

Finally, it may be well to mention here that the motivation in exploring this kind of approach to $\mathrm{P} 4 \mathrm{wC}$ is to primarily address the challenges in an ethnically-diverse COI, particularly the groups of children I encountered in my own locale (i.e., Mindanao, Philippines). While my experiences are specific to my particular location, I think it is not farfetched to assume that these challenges also occur in other areas with various ethno-linguistic communities. Looking at the approximate number of indigenous learners in the Philippine public education system, one becomes concerned of their educational experiences, knowing that the standard curriculum and pedagogy used in public schools are not always sensitive and responsive to their cultures. ${ }^{5}$ In this regard, a culturally-enabling $\mathrm{P} 4 \mathrm{wC}$ could offer pedagogical possibilities that can address the situation of indigenous children who are gradually assimilated in the mainstream through public education.

\section{references}

Alcoff, Linda. "Cultural Feminism versus Post-structuralism: The Identity Crisis in Feminist Theory." in Signs, Vol. 13, No. 3, 1988, pp. 405-436

Bruya, Brian. "Ethnocentrism and Multiculturalism in Contemporary Philosophy," in Philosophy East and West, Volume 67, Number 4, 2017, pp.991-1018.

Echeverria, Eugenio "Philosophy for Children with indigenous children." in Children Philosophize Worldwide: Theoretical and Practical Concepts, Frankfurt am Main: Peter Lang, 2009, pp.663-668.

\footnotetext{
${ }^{5}$ It is laudable that the Department of Education in the Philippines, through its Indigenous Peoples Education (IPed) Program has responded to the "right of indigenous peoples (IP) to basic education that is responsive to their context, respects their identities, and promotes the value of their indigenous knowledge, skills, and other aspects of their cultural heritage" (DepEd Order No. 62, s. 2011). Though enacted in 2011, it is yet to be known whether its aims have been truly achieved.
} 
i am keeping my cultural hat on: exploring a 'culture-enabling' philosophy for/with children practice

Elicor, Peter Paul. "Resisting the 'View from Nowhere': Positionality in Philosophy for/with Children Research," in Philosophia International Journal of Philosophy, Vol. 21, No.1, 2020, pp.19-33.

Gatmaytan, Augusto B. "The Hakyadan of Froilan Havana: Ritual Obligation in Manobo Religion," in Philippine Studies, Vol. 52, No. 3, Nature-Culture, 2004, pp. 383-426.

Gay, Geneva. Culturally Responsive Teaching: Theory, Research, and Practice. New York \& London: Teacher College Press, 2000.

Hong, Ying-yi, Michael W. Morris, Chi-yue Chiu, Veronica Benet-Martinez. "Multicultural Minds: A Dynamic Constructivist Approach to Culture and Cognition," in American Psychologist, Vol. 55, Number 7, 2000, pp.709-720.

Jackson, Thomas. "Homegrown." in Educational Perspectives, 44 (1\&2), 2012, pp.3-7.

Kohan, Walter Omar. "The Origin, Nature, and Aim of Philosophy in Relation to Philosophy for Children." in Thinking, 12(2), 1995, pp.25-30.

Kohan, Walter Omar, "Paulo Freire and Philosophy for Children: A Critical Dialogue," in Studies in Philosophy and Education, May 2018, https://doi.org/10.1007/s11217-0189613-8

Makaiau, Amber Strong. “Philosophy for Children Hawai'i A Culturally Responsive Pedagogy for Social Justice Education," in Inclusion, Diversity, and Intercultural Dialogue in Young People's Philosophical Inquiry, edited by C.-C. Lin \& L. Sequeira, Rotterdam: Sense Publishers, 2017, pp. 99-110.

Oliverio, Stefano. "Intercultural Philosophy and the Community of Philosophical Inquiry as the Embryonic Cosmopolitan Community." in Inclusion, Diversity, and Intercultural Dialogue in Young People's Philosophical Inquiry, edited by C.-C. Lin \& L. Sequeira, Rotterdam: Sense Publishers, 2017, pp.3-14.

Preece, Abdul Shakour \& Adila Juperi. "Philosophical Inquiry in the Malaysian Educational System -Reality or Fantasy?" in Analytic Teaching and Philosophical Praxis, Volume 35, Issue 1, 2014, pp. 26-38.

Qin, Dongxiao. "Positionality," in The Wiley Blackwell Encyclopedia of Gender and Sexuality Studies, First Edition, edited by Nancy A. Naples, JohnWiley \& Sons, Ltd., 2016.

Santi, Marina. "Doing Philosophy in the Classroom as Community Activity: A CulturalHistorical Approach." in childhood E philosophy, Vol. 10, No. 20, 2014, pp.283-304.

Maher, Frances A. and Mary Kay Tetreault. "Frames of Positionality: Constructing Meaningful Dialogues about Gender and Race." in Anthropological Quarterly, Vol. 66, No. 3, 1993, pp. 118-126.

Tibaldeo, Roberto Franzini. “Responsibility Towards Diversity: An Educational Proposal for the Enhancement of Democracy," in Intercultural Education and Competences Challenges and Answers for the Global World, edited by Agostino Portera and Carl A. Grant, Newcastle: Cambridge Scholars Publishing, 2017, pp.115-128.

Turgeon, Wendy. "Multiculturalism: Politics of difference, education, and philosophy for children." in Analytic Teaching, 24(2), 2005, pp.96-109.

received in: 31.08 .2020

approved in: 13.11 .2020 